\title{
Tomhændet må ingen se mit ansigt! Gavens teologi i Det Gamle Testamente ${ }^{1}$
}

\author{
Professor (mso), ph.d. \\ Anne Katrine de Hemmer Gudme, Københavns \\ Universitet
}

\begin{abstract}
The Theology of the Gift in the Hebrew Bible. This article promotes an understanding of sacrifices in the Hebrew Bible as foodgifts to Yahweh. It is claimed that a proper understanding of gift-giving as an open-ended social practice that establishes lasting relationships between the exchanging parties can help us understand the role and function of sacrifices in the Hebrew Bible. In light of this, sacrifices as food for Yahweh, child sacrifice and the prophetic cult criticism are discussed.
\end{abstract}

Keywords: Hebrew Bible - sacrifices - offerings - gift giving - child sacrifice - cult criticism - reciprocity - almsgiving.

\section{Det blodige offer}

Det blodige offer er et godt eksempel på noget, der er meget fremmed og eksotisk og temmelig uforståeligt. For hvad i alverden er det, der får mennesker til at slagte et dyr, skære det i mindre stykker, og brænde hele eller dele af dyret på et brændofferalter? ${ }^{2}$ Det blodige offer har tiltrukket sig megen opmærksomhed blandt religionshistorikere, og det er der flere gode grunde til. Først og fremmest er selve ritualet ganske spektakulært. Det indebærer et drab på offerdyret, ofte en eller anden form for håndtering af dyrets blod, og til slut hel eller delvis afbrænding af dyrets krop på et alter. Afbrændingen "overfører" offerdyret til den eller de guddomme, som det er dedikeret til. ${ }^{3}$ Når det

1. Denne artikel er en let revideret udgave af min tiltrædelsesforelæsning, som jeg gav fredag den 7. marts 2014 på Det Teologiske Fakultet i København. Jeg skylder min anonyme bedømmer stor tak for grundig gennemlæsning og mange nyttige kommentarer og ændringsforslag.

2. Det blodige offer hører til i den gruppe af ritualer som Catherine Bell kalder "Rites of Exchange and Communion", se Ritual: Perspectives and Dimensions (Oxford: Oxford University Press 1997), 108-114, i Det Gamle Testamente findes den mest udførlige beskrivelse af det blodige offer i 3 Mos 1-7.

3. I Det Gamle Testamente er slagtning og hel eller delvis afbrænding den grundlæggende offermetode, når det gælder blodige ofre. I det hele taget er ofre, hvor 
kun er dele af dyret, der brændes, ledsages det blodige offer ofte af et fællesmåltid for offerbringeren og hans følge. Hertil kommer, at det blodige offer er ualmindelig velrepræsenteret i religionshistorien. Det dukker op i nogle af de tidligste tegn på religiøs adfærd, vi kender til, og der er eksempler på blodige ofre i stort set alle dele af verden. I de rituelle systemer i antikkens Grækenland og i Rom havde det blodige offer en central plads i tempelkulten, og det har uden tvivl også bidraget til interessen for netop dette ritual. ${ }^{4}$ Det er naturligvis heller ikke uvigtigt, at intet andet ritual fylder så meget i Det Gamle Testamente som det blodige offer.

I religionshistoriens barndom i sidste halvdel af det 19. århundrede blev der brugt mange kræfter på at forklare det blodige offers oprindelse og funktion. I dag er de store universelle forklaringer på fænomeners opståen mere eller mindre gået af mode, men studiet af det blodige offer er stadig i høj grad påvirket af de tidlige "store" teorier. Hvis man stiller det firkantet op, og det kan jo af og til have sine fordele, falder teorier om det blodige offer typisk inden for en af tre kategorier, der til dels overlapper hinanden. De tre kategorier er: det blodige offer som gave, det blodige offer som måltid og det blodige offer som lynafleder. ${ }^{5}$

Edward B. Tylor var den første, der byggede en storstilet teori op omkring det blodige offer som en gave til guderne. ${ }^{6}$ Tylors grundlæggende ide er sådan set aldrig blevet tilbagevist, men Tylors teori er senere blevet kritiseret for ikke at kunne forklare alle aspekter af det blodige offer, især fællesmåltidet, for kan noget nu også kaldes en

røgen stiger opad til Jahve på en vertikal akse, det dominerende offermodus i Det Gamle Testamente. I modsætning til eksempelvis Mesopotamien og Egypten, hvor præsentationsofre, ofre der præsenteres for guden på en horisontal akse, er dominerende (jf. James W. Watts, “olah: The Rhetoric of Burnt Offerings”, VT 56 (2006), 125-137; Michael B. Hundley, Keeping Heaven on Earth: Safeguarding the Divine Presence in the Priestly Tabernacle (Tübingen: Mohr-Siebeck 2011), 110 med henvisninger). Se også diskussionen i Anne Katrine de Hemmer Gudme, "If I were hungry, I would not tell you" (Ps 50:12): Perspectives on the Care and Feeding of the Gods in the Hebrew Bible", SJOT 28 (2014), 170-182.

4. Se Richard E. DeMaris, "Sacrifice, an Ancient Mediterranean Ritual", BTB 43 (2013), 60-73, for en god og kortfattet introduktion til offeret i middelhavsområdet i oldtiden.

5. Af pladshensyn har jeg holdt min gennemgang af de store offerteorier meget kort, og med et primært fokus på teorier, der relaterer til Det Gamle Testamente. Se Jeffrey Carter (red.), Understanding Religious Sacrifice: A Reader (London: Continuum 2003) for et bredere udsnit.

6. Edward B. Tylor, Primitive Culture: Researches into the Development of Mythology, Philosophy, Religion, Language, Art and Custom. 2 vol. (London, UK: John Murray ${ }^{4} 1903$ [1871]). Tylors teori var grundlæggende et forsøg på at forklare religionens udvikling, og derfor arbejdede han med tre faser: gaven, måltidet og askese eller afsavn, se særligt bind 2, side 375-99. 
gave, hvis giveren spiser størstedelen af offerdyret selv? Den kritik vil jeg vende tilbage til nedenfor. I en dansk eksegetisk kontekst bør man nævne Johannes Pedersen her, som også understregede det blodige offers grundfunktion som gave i Det Gamle Testamente. ${ }^{7}$

Det er især William Robertson Smith, der forbindes med teorien om offeret som måltid. ${ }^{8}$ Robertson Smith lagde særlig vægt på fællesskabet i måltidet, dels den forbundenhed, der opstår indbyrdes blandt gruppens medlemmer, dels den nærhed, der skabes mellem gruppen og guddommen. Robertson Smiths teori havde rod i en forestilling om universel totemisme, hvor offerdyret var gruppens totemdyr og således også dens guddom. Fællesskabet mellem en guddom og et menneske i offermåltidet sker altså ikke fordi begge parter spiser af det samme dyr, men fordi offerdyret $e r$ guddommen, og ved at spise det opnår mennesker en form for forening med guddommen (Smith 1889, 363). Når man læser Robertson Smith, er det vanskeligt ikke at se spøgelser af den kristne nadver overalt i teksten, og hans arbejde med det blodige offer er da også blevet kritiseret heftigt i løbet af de sidste godt og vel 100 år, men vigtigheden af offeret som måltid har overlevet. ${ }^{9}$ I de seneste år har synet på offeret som måltid dog bevæget sig i retning af, at det paradoksalt nok er et fællesskab, der har til hensigt at demonstrere en grundlæggende forskellighed. ${ }^{10}$ Gud og mennesker "spiser" af det samme offerdyr, og derfor bindes de sammen, men fordi de samtidig spiser på en vidt forskellig måde, og ganske ofte også tildeles forskellige dele af offerdyret, udfolder offermåltidet en lære om det menneskelige og det guddommeliges grundlæggende forskellighed. ${ }^{11}$ I en dansk kontekst er det især Hans Jørgen Lundager

7. Johannes Pedersen, Israel III-IV: Hellighed og Guddommelighed (København: Povl Branner 1934), 250-253.

8. William Robertson Smith, The Old Testament in the Jewish Church. A course of lectures on biblical criticism (Edinburgh: A. \& C. Black 1881); Lectures on the Religion of the Semites. First Series. The Fundamental Institutions (New York, NY: D. Appleton, 1889), særligt side 227, 369-77, 381 og 418.

9. Se Christian Eberhart, Studien zur Bedeutung der Opfer im Alten Testament: Die Signifikanz von Blut- und Verbrennungsriten im kultischen Rahmen (NeukirchenVluyn: Neukirchener Verlag, 2002), 190-191 og 201-203 for en god sammenfatning af teori og kritik.

10. Se eksempelvis David Janzen, The Social Meanings of Sacrifice in the Hebrew Bible: A Study of Four Writings (Berlin: Walter de Gruyter 2004), 112-114; Jonathan Klawans, Purity, Sacrifice and the Temple: Symbolism and Supercessionism in the Study of Ancient Judaism (Oxford: Oxford University Press 2006) 57-68; Alfred Marx, Les systems sacrificiels de l'Ancien Testament: Formes et fonctions du culte sacrificial à Yhwh (Leiden: Brill 2005), 140-142.

11. Jean-Pierre Vernants arbejde med det græske thysia (også en form for måltidsoffer) har haft stor indflydelse på denne diskussion, se "At Man's Table: Hesiod's Foundation Myth of Sacrifice", The Cuisine of Sacrifice among the Greeks, red. Mar- 
Jensen, der har været med til at overføre denne forståelse af det blodige offer på det gammeltestamentlige måltidsoffer. ${ }^{12}$

Den sidste kategori, det blodige offer som lynafleder, lyder måske en anelse gådefuld, men det jeg mener med lynafleder er, at offerdyret på den ene eller den anden måde fungerer som et stedfortrædende offer, der afleder alskens negative tendenser og dårligdomme, så de ikke rammer gruppen og gør dens medlemmer fortræd. ${ }^{13}$ Sir James George Frazer var en af de første, der leverede en udgave af denne teori i form af sine tanker om den guddommelige konge, der blev ofret for at gøre plads til en yngre og stærkere model. Drabet på den gamle gudekonge var en nødvendighed for at styrke og revitalisere samfundet, og dette skete blandt andet ved at lade den døende gud fungere som en form for syndebuk, der bar al gruppens forfald og dårligdom med sig. ${ }^{14}$ Et andet eksempel på en lynafleder-teori er Sigmund Freuds ideer om, at det blodige offer i virkeligheden er en genopførelse af et urgammelt fadermord, men samtidig også en mulighed for at udleve iboende morderiske tendenser. Et menneske vokser op med et grundlæggende had til faderfiguren, og i det blodige offer kanaliseres dette had, og den deraf følgende vold, over på offerdyret. ${ }^{15}$ Endnu et berømt eksempel på en lynaflederteori er René Girards tanker om offerdyret som syndebuk. Girard opfattede offerdyret som samfundets prügelknabe, og ved regelmæssig gentagelse af det blodige offer kunne en gruppe på velordnet og uskadelig vis få afløb for den underliggende aggression og trang til vold, som ifølge Girard altid vil være til stede. ${ }^{16}$ Her er det også på sin plads at nævne Walter Burkert. Burkert beskæftigede sig primært med offerritualer i oldtidens Grækenland, og inspireret af Karl Meuli opfattede han jagten som det blodige offers naturlige oprindelse. ${ }^{17}$ Med jagten opstod også muligheden for

cel Detienne og Jean-PierreVernant, (Chicago: University of Chicago Press 1989), 21-86.

12. Hans Jørgen Lundager Jensen, Den Forterende Ild: Strukturelle analyser af narrative og rituelle tekster $i$ Det Gamle Testamente (Aarhus: Aarhus Universitetsforlag 2000), 278-279.

13. Med til lynaflederkategorien regner jeg også de teorier, hvor vægten er på det stedfortrædende, snarere end det decideret afværgende, se en god sammenfatning i Eberhart (2002), 191-198.

14. James George Frazer, The Golden Bough: A Study in Magic and Religion (London: Macmillan and Co., Ltd. 1911-1915), 309-313.

15. Sigmund Freud, Totem and Taboo: Resemblances between the Psychic Lives of Savages and Neurotics, (New York: Random House 1961 [1918, tysk udg. 1913]), 181-207.

16. René Girard, La Violence et le Sacré (Paris: Bernard Grasset 1972).

17. Walter Burkert, Homo Necans. Interpretationen altgriechischer Opferriten und Mythen, RVV 32 (Berlin: de Greuyter 1972), 20-31; Karl Meuli, "Griechischen Opferbräuche”. Gesammelte Schriften Band 2 (Basel: Schwaben 1976), 907-102. 
drab mellem mennesker. For at undgå, at det løb løbsk, måtte man systematisere jagten og drabet på offerdyret i form af en række ritualer, der så at sige hegnede volden ind. Sidenhen kom domesticeringen af husdyr og brugen af dem som offerdyr, men derved også skyldfølelsen over at have taget et liv, som man selv havde opfostret. Denne skyldfølelse førte til et behov for at dedikere offerdyret til det hellige som en form for soning for drabet. ${ }^{18}$

Dette bringer mig til Jacob Milgrom. Man kan ikke tale om det blodige offer i Det Gamle Testamente uden at nævne Milgrom og hans enorme arbejde med at analysere og fortolke ritualteksterne $\mathrm{i}$ Tredje Mosebog og især de rituelle love, der har med offeret at gøre. ${ }^{19}$ Milgrom forstod offertypen חטאת, som det mest centrale blodige offer i det gammeltestamentlige offerrepertoire. חטאת oversættes traditionelt som syndofferet (jf. 3 Mos 4,1-5,13; 6,17-23), men på baggrund af Milgroms arbejde bruges nu i stigende grad betegnelsen renselsesofferet. ${ }^{20}$ Blodet fra renselsesofferet fungerede som en form for rituelt rengøringsmiddel, der kunne bruges til at rense helligdommens allerinderste rum, hvor Jahve opholdt sig, for urenhed og synd. ${ }^{21}$ Denne renselsesproces kulminerede en gang om året på Forsoningsdagen, hvor ypperstepræsten stænkede offerdyrets blod i det allerhelligste (3 Mos 16). Milgrom lagde stor vægt på soning (כפר) og renselse i sin forståelse af offeret, og han forestillede sig - lidt på linje med Burkert - at blodmanipulationen, der ledsagede ethvert slagtoffer i Det Gamle Testamente, tjente til en form for soning for drabet på offerdyret. ${ }^{22}$ Milgroms arbejde har stadig massiv indflydelse på forståelsen

18. Burkert 1972, 31-38; se Hans Jørgen Lundager Jensen, "Genese og funktion - offeret ifølge Walter Burkert”, RvT 20 (1992), 25-46, for en god dansksproget introduktion til Burkert.

19. Hovedpointerne i Milgroms arbejde sammenfattes i hans imponerende kommentar til 3 Mos., som blev udgivet i Anchor Bible kommentarserien fra 1991-2001. I forhold til det blodige offer er bind 1, Leviticus 1-16, det mest relevante. En mere tilgængelig fremstilling findes i Leviticus: A Book of Ritual and Ethics (Minneapolis: Fortress Press 2004), og en samling af Milgroms tidlige artikler findes i Studies in Cultic Theology and Terminology (Leiden: Brill 1983).

20. Milgrom (1991), 253-254; Se den grundige diskussion af hattat i Eberhart (2002), 230-267.

21. Se især "Israel's Sanctuary: The Priestly 'Picture of Dorian Gray", Revue Biblique 83 (1976), 390-99.

22. Se især "The Biblical Diet Laws as an Ethical System”, Interpretation 17 (1963), 288-301, hvor Milgrom gør rede for, hvordan netop kravet om at hælde blodet fra offerdyret og dermed sone for drabet, skærper den etiske sans hos Israel, se også Lundager (2000), 270-272. En interessant og opdateret diskussion af blodriters funktion i Det Gamle Testamente findes i William K. Gilders, Blood Ritual in the Hebrew Bible: Meaning and Power (Baltimore, MD: Johns Hopkins University Press 2004). 
af det blodige offer i Det Gamle Testamente, men der er også nye tendenser, der forsøger at udfylde nogle af hullerne i Milgroms teori. Det største problem i forhold til Milgrom må siges at være, at hvis renselsesofferet er så vigtigt, hvad skal man så overhovedet med alle de andre offertyper?

En tungtvejende kritik af Milgrom, og af lynaflederteorier i det hele taget, er at disse fortolkninger af det blodige offer tillægger drabet på offerdyret meget stor vægt. Det er der på sin vis ikke noget at sige til, for der er jo noget ganske opsigtsvækkende ved det ceremonielle drab og den efterfølgende håndtering af offerdyrets blod. ${ }^{23}$ Det massive fortolkningspotentiale er ikke vanskeligt at få øje på. Problemet er bare, at oldtidens forfattere og billedkunstnere tilsyneladende var af en anden opfattelse. Der er intet tegn på, hverken i Det Gamle Testamente eller i anden oldtidslitteratur, at drabet i forbindelse med det blodige offer blev anset for at være væsentligt eller centralt (Eberhart 2002, 203-216). Det var snarere en nødvendig forudsætning for at kunne skære offerdyret i stykker, håndtere dets blod, brænde det og måske spise det. ${ }^{24}$ Drabet synes at være et middel til et mål, og ikke selve formålet med det blodige offer. Når først man er nået frem til denne konklusion, ligger det også ligefor, at det kun giver begrænset mening at fokusere udelukkende på det blodige offer, for det er klart at slagtofrene udgør en del af et større rituelt system, der også omfatter røgelsesofre, afgrødeofre og drikofre. Hertil kommer muligheden for at dedikere uforgængelige genstande til templet og til Jahve, det er det man kalder votivobjekter, og pengegaver i form af krigsbytte og afgifter og så videre. Og det bringer mig tilbage til kategori nummer 1, nemlig det blodige offer som gave, for det er her, tror jeg, at vi finder det tætteste vi kommer på en forklaring på offeret i Det Gamle Testamente.

Hvis vi ser på, hvad Det Gamle Testamente selv "siger", så kaldes offeret ganske ofte מנחה, som slet og ret betyder gave. מנחה kan bruges både om gaver, der udveksles mellem mennesker, og om gaver fra mennesker til gud. Et andet hyppigt brugt udtryk er קרבן, som bruges specifikt om offergaver. קרבן קרב kommer af roden, som betyder at nærme sig eller bringe noget nær, og קרבן betyder således det, som man bringer hen til Jahve i templet. ${ }^{25}$ Endelig har vi Jahves eget ud-

23. Se Anne Katrine de Hemmer Gudme, "Der er ingen vampyrer i Det Gamle Testamente: Blod, liv og konceptuelle metaforer”, Den store fortalling, red. Søren Holst og Christina Petterson (København: Anis 2012), 173-184.

24. Kathryn McClymond, Beyond Sacred Violence: A Comparative Study of Sacrifice (Baltimore, MD: Johns Hopkins University Press 2008), 44-64.

25. Eksempelvis i 1 Mos 4. I de såkaldt præsteskriftlige tekster refererer מנחה udelukkende til afgrødeofferet, jf. Anne Katrine de Hemmer Gudme, Before the God 
sagn, som vi får hele to gange, nemlig både i Anden Mosebog 23,15 og 34,20: "tomhændet må ingen se mit ansigt", eller med andre ord, "I må ikke komme og besøge mig i templet, hvis I ikke har en gave med."

\section{Gaven}

En grundforståelse af offeret som gave giver rigtig god mening, men det kræver naturligvis, at den hviler på en korrekt forståelse af gavegivning i det hele taget. ${ }^{26}$ Det er fejlagtige opfattelser af gavegivning, der har resulteret $\mathrm{i}$, at ideer om offeret som gave har været udsat for massiv kritik. ${ }^{27}$ For hvad er dog det for en guddom, der lader sig bestikke, og hvad er det dog for nogle usle tilbedere, der giver guden et offer, og så ender med at spise næsten det hele selv?28 Problemet er, at mange, der beskæftiger sig med gavegivning, i for høj grad hæfter sig ved, at der er tale om en udveksling, et bytteforhold. Man fokuserer på de ting, der udveksles, og deres relative værdi, og går derved glip af det, der sker mellem parterne i udvekslingen. ${ }^{29}$ Hvis nu man skal bruge et billede fra sportens verden, og det er jo så moderne, så har folk alt for travlt med at holde øje med bolden, når de i virkeligheden burde kigge på spillerne. Gavegivning er i virkeligheden en utrolig raffineret social praksis, der skaber relationer mellem mennesker eller

\footnotetext{
in this Place for Good Remembrance: A Comparative Analysis of the Aramaic Votive Inscriptions from Mount Gerizim (Berlin: De Gruyter 2013), 39-41.

26. De fleste diskussioner af gavegivning tager udgangspunkt i Marcel Mauss' "Essai sur le don" (engelsk oversættelse: The Gift: The form and reason for exchange in archaic societies [London: Routledge 1990], som blev udgivet i 1925). Se Mark Osteen (red.), The Question of the Gift: Essays across disciplines (London: Routledge 2002), for en spændende og tidssvarende introduktion til gavegivningsteori. I forhold til studiet af gavegiving i oldtidssamfund anbefales Gill, Postlethwaite \& Seaford (red.), Reciprocity in Ancient Greece (Oxford: Oxford University Press 1998) og Michael Satlow (red.), The Gift in Antiquity (Malden: Wiley-Blackwell 2013). Den følgende diskussion af gaven bygger på min artikel "The Biblical Vow as Barter Deal or Friend-Making Gift: A Reconsideration of the Conditional Vow in the Hebrew Bible", The Gift in Antiquity, red. Michael Satlow (Malden: Wiley-Blackwell 2013), 189-201, og Gudme (2013), 18-36.

27. Se den glimrende diskussion i Daniel Ullucci, The Christian Rejection of Animal Sacrifice (Oxford: Oxford University Press 2011), 15-30.

28. Se Jan van Baals kritik af Tylor, "Offering, Sacrifice and Gift." Numen 23 (1976), 161-178.

29. Denne skelnen hænger sammen med forholdet mellem gavegivning og handel (jf. Gudme (2013), 22-24), se C.A. Gregory, Gifts and Commodities (London: Academic Press 1982), og en interessant kritik af denne skelnen i Ullucci (2011), 25-26.
} 
mellem mennesker og guder. ${ }^{30}$ For den objektive tilskuer, der har mulighed for at betragte gavegiving sådan lidt fra oven, så er det klart, at der er tale om et bytte forhold; man er "på gave" med hinanden, og skiftes derved til at give hinanden gaver, der sådan nogenlunde stemmer overens med hensyn til pris, grad af intimitet og personlighed osv. Men for de personer, der er involveret i udvekslingen, tager det sig anderledes ud. Her er det nemlig vigtigt, at prisen er hemmelig - vi piller pligtskyldigt mærkaten af - og at gaven virker generøs, spontan og personlig. Selvom gaveudveksling mellem ligestillede ofte har en tendens til være retfærdig, sådan at man sjældent over tid giver væsentligt mere, end man får, man kan ligefrem aftale en prisramme for dette års julegaver, så er en af pointerne ved gavegivning, at udvekslingen netop ikke må være retfærdig, man må endelig ikke blive 'kvit', for i det øjeblik man "står lige", så er transaktionen afsluttet, og man er ikke længere forbundet gennem udveksling. ${ }^{31}$ Gavegivning skaber relationer mellem mennesker, fordi man skiftes til at være i taknemmelighedsgæld til hinanden, og den relation kan fortsætte lige så længe, man sørger for ikke at gøre regnskabet op. ${ }^{32}$ Hvis man ser på gavegivning mellem personer, der ikke er ligestillede, det kunne eksempelvis være et barn og en forælder, så bliver uligheden, eller uretfærdigheden om man vil, endnu tydeligere. Der er jo stor forskel på den store Lego-borg og et hjemmelavet askebæger, men det er faktisk ikke vigtigt, for det handler om spillerne, husker vi nok, og ikke om bolden. Det der er vigtigt er, at gaven er personlig, og at alle giver efter bedste evne, for så holder relationen. Hvis gavegivning skal lykkes, så kræver det faktisk en god portion takt og social indsigt, gaven skal målrettes og tilpasses til situationen og til modtageren. Gaven fortæller næsten altid en historie om relationen - hvis en mand giver gaver til to kvinder, og den ene får silkeundertøj og den anden får en foodprocessor, hvem af de to er så hans hustru, og hvem er hans elskerinde (jf. Osteen 2002, 20-21)?

Hvis man betragter det ovenfra, så kan gavegivning virke mekanisk og bundet, og derfor fuldstændig trygt og forudsigeligt, men sådan er det ikke for spillerne på banen. Gavegivning er en risikabel affære,

30. Allerede Mauss påpegede gavens potentiale som "social lim” (Mauss (1990), 16-17, 42. Se også Marshall Sahlins, Stone Age Economics (London: Routledge 2004 [1974]), 186.

31. Mauss kaldte disse tilsløringer for gavens høflige fiktion, se Mauss (1990), 4 og $94 \mathrm{og}$ en videreudvikling af dette tema i Pierre Bourdieu, Outline of a Theory of Practice (Cambridge: Cambridge University Press 1977), 4-5; The Logic of Practice (Cambridge: Polity Press 1990), 98-99 og 105.

32. Jacques T. Godbout og Alain Caillé, The World of the Gift (Montreal: McGillQueen's University Press 1998), 5, 32-33, 129-130. 
hvor udfaldet aldrig er givet på forhånd, for idet man sender gaven af sted, har man blottet sig, og modtageren af gaven har krammet på en. Man kan risikere, at modtageren sender gaven tilbage, eller at man aldrig hører fra vedkommende igen, i begge tilfælde går relationen itu, og gaven har ikke kunnet udvirke sin særlige sociale magi. En gave, der er givet, er en udfordring eller en invitation, og kun tiden kan vise, hvordan udfordringen tages op (jf. Van Baal 1976). Det er der et rigtig godt eksempel på i Det Gamle Testamente i Første Mosebog 23. Patriarken Abraham har mistet sin hustru, Sara, og nu skal han finde et sted, hvor han kan begrave hende. Derfor opsøger han hittitterne, som ejer jorden i området, for at erhverve Makpelas hule til begravelsen. ${ }^{33}$ Abraham får tilbudt jorden som en gave, men det vil han ikke tage imod, for han vil ikke stå i taknemmelighedsgæld til hittitterne. Det er simpelthen ikke en relation, han er interesseret $i$. Derfor bliver han ved med at sige, at han vil betale den fulde pris for jorden, så er det nemlig ikke en gave, men en handel. Hittitten Efron, som ejer jorden, prøver igen, og siger, at han vil give jorden til Abraham som en gave, men Abraham spørger efter prisen en gang til, og så bøjer Efron sig og nævner en pris, sådan at transaktionen afsluttes som køb og salg. Når prisen er betalt, er man kvit, og så behøver man ikke længere at have noget med hinanden at gøre, og det er det, Abraham vil have. ${ }^{34}$

En gave er altid i fare for at blive afvist, og det er alvorligt, for det er ikke gaven, man siger nej til, det er giveren. Sådan er det også i historien om Kain og Abel i Første Mosebog 4. Jahve siger ja tak til Abels offergave og nej tak til Kains, men det er ikke fordi, Jahve bedre kan lide slagtofre end afgrødeofre, det er fordi Jahve tilsyneladende bedre kan lide Abel, end han kan lide Kain. ${ }^{35}$ Et sammenbrudt gudsforhold er det, som den afviste offergave indikerer, og så er det måske slet ikke så svært at forstå, at det gik som det gik med Kain og Abel. Problemet

33. Dette eksempel har jeg tyvstjålet fra Gary Stansell, "The Gift in Ancient Israel", Semeia 87 (1999), 65-90.

34. Se Hans Jørgen Lundager Jensen, “Abraham, høflighedens ridder”, DTT 74 (2011), 3-21 (12-13), for en analyse af denne passage, der lægger vægt på Abrahams næse for købmandsskab. I modsætning til Lundager Jensen tror jeg ikke, at det er forfatterens pointe, at Abraham forstår sig på handel og på hittitterne. Jeg læser 1 Mos 23 som langt mere afvisende overfor fredelig sameksistens og samhandel, jf. Francesca Stavrakopoulou, Land of our Fathers: The Roles of Ancestor Veneration in Biblical Land Claims (New York: T\&T Clark 2010), 29-38.

35. Jahves afvisning af Kains offergave har længe været et problem for fortolkere af 1 Mos 4. Allerede i LXX forsøgte man at skelne mellem de to offergaver, der begge kaldes מנחה i MT, ved at oversætte Abels offergave med "gave" og Kains med "offer". Desuden antydes det i LXX, at Kain har ofret forkert. Se Lizette Harritsø, "Kainfortællingen i antikke oversættelser og fortolkninger”, DTT 75 (2012), 187-202. 
med at give og modtage gaver fra guderne er, at de ikke altid udtrykker sig helt klart. Hvordan ved man, at en gave er modtaget eller afvist? Kain var ikke i tvivl, men for det meste er det mere kompliceret end som så. Er en dårlig høst eller et gedekid med to hoveder tegn på, at Jahve har afvist relationen? I sidste ende bliver det et spørgsmål om tro og fortolkning, og under alle omstændigheder er det nok bedst at sørge for at Jahve får, hvad han vil have, for han har jo selv sagt det, "tomhændet skal ingen se mit ansigt".

\section{Jahves ønskeseddel}

Og hvad er det så, Jahve ønsker sig? Jahve er meget glad for røgen fra de blodige ofre og afgrødeofre, der brændes på brændofferalteret. Den røg kaldes "en liflig duft" (ריח־ניחוח), og da Jahve indånder røgen fra Noas første brændofre efter Syndfloden i Første Mosebog 8,21, bliver han så glad, at han siger til sig selv, at han aldrig mere vil forbande jorden og forsøge at udrydde alt levende på dens overflade. Jahve lægger særlig vægt på offerrøgen, den liflige duft, fordi han så at sige "spiser" med næsen. ${ }^{37}$ Røgen fra ofrene er simpelthen Jahves mad. Jahve siger det selv til Moses i Fjerde Mosebog 28: "Giv israelitterne befaling om at sørge for at bringe mig min gave (קרבני), min offerspise (לאשי לחמי), en liflig duft, til den fastsatte tid." ${ }^{38}$ Brændofferalteret kaldes ligefrem for Jahves (spise)bord (שלחן) i nogle tekster. ${ }^{39}$ De slagtofre og afgrødeofre, der brændes på alteret, er altså madgaver til Jahve. På den måde har teori nummer to jo også ret, for offeret fungerer tydeligvis også som Jahves måltid. Jeg vil bare påstå, at gave-motivet er vigtigere end måltids-motivet. Det er der to grunde til: for det første synes Det Gamle Testamente selv at lægge større vægt på offeret som gave end som mad. Det kan man se ved en simpel sammentælling af, hvor ofte ofrene betegnes som gaver og offergaver i forhold til, hvor ofte de

36. Jf. Robin Osborne, "Hoards, Votives, Offerings: The Archaeology of the Dedicated Object", World Archaeology 36 (2004), 1-10 (2). I det gamle Grækenland kunne offerdyrets hale 'læses' som et tegn på, om offeret var modtaget af guddommen (jf. Folkert van Straten, "The God's Portion in Greek Sacrificial Representations: Is the tail Doing Nicely?”, Early Greek Cult Practice, red. Robin Hägg, Nanno Marinatos og Gullög C. Nordquist (Stockholm: Paul Åströms Förlag 1988), 51-68 ), men en sådan fortolkningsmekanisme findes ikke i Det Gamle Testamente.

37. Jf. Lundager Jensen (2000), 291-293; Marx (2005), 139; Christian Eberhart, "A Neglected Feature of Sacrifice in the Hebrew Bible: Remarks on the Burning Rite on the Altar," Harvard Theological Review 97 (2004), 485-493.

38. Jf. 3 Mos 21,6.

39. Ez 41,22 og 44,16; Mal 1,7 og 1,12. 
kaldes offerspise. For det andet er jeg en stor tilhænger af gaveteorien, fordi den hjælper os til at forstå hele spektret af offergaver, og ikke kun de ofre, der brændes på alteret, og derved omdannes til røg, som Jahve kan spise. En forståelse af det blodige offer som gave giver os mulighed for netop at se det i sammenhæng med røgelsesofre, afgrødeofre, drikofre, votivobjekter og pengegaver.

Hvis vi dvæler et øjeblik ved slagtofre og afgrødeofre som madgaver til Jahve, er det klart, at det har været vigtigt for de gammeltestamentlige forfattere, at man har forstået det "rigtigt". I ritualteksterne i Anden, Tredje og Fjerde Mosebog understreges det, at ofrene netop er en liflig duft, og at de er "ildofre" (אשה), det vil sige at transformationen af offersubstansen ved hjælp af ild er en vigtig forudsætning for, at Jahve kan modtage ofrene. ${ }^{40}$ På den måde lægger forfatterne vægt på, at Jahve ikke spiser på samme måde som mennesker, men man må sige, at de gør det på en temmelig indirekte måde. Hvis man derimod vender sig til den fortællende litteratur i Det Gamle Testamente, foldes den samme pointe ud i to historier i Dommerbogen 6 og 13. Historierne minder til forveksling om hinanden, så jeg nævner kun den ene her. I Dommerbogen 13 hører vi om, hvordan Samsons mor får besøg af Jahves engel, som fortæller hende, at hun skal føde en søn, nemlig Samson. Samsons far hedder Manoa, og han har ikke helt fanget, at den mand, der er kommet på besøg for at tale med hans kone, i virkeligheden er en guddommelig budbringer. Ikke desto mindre lader det til, at Manoa anser ham for at være en fornem gæst, og Manoa er gæstfri, så han inviterer ham på middag og siger: "Kan vi ikke overtale dig til at blive her, så vil vi tilberede et gedekid til dig." Men englen svarer Manoa: "Selv om du fik mig overtalt, ville jeg ikke spise din mad. Men hvis du vil bringe et brændoffer, så skal du ofre det til Jahve.” Det gør Manoa så. Han henter et gedekid og et afgrødeoffer, og ofrer begge dele på klippen til Jahve, og i det øjeblik flammerne slikker om offeret på alteret, springer englen op $\mathrm{i}$ ilden og forsvinder! Og så går det op for Manoa, hvad hans mystiske gæst i virkeligheden var. Moralen her synes at være klar; Jahve og mennesker kan godt spise de samme ting, men de spiser dem på vidt forskellig vis, og det er fordi, der er grundlæggende forskel på Jahve og mennesker. Hvis man stadig er i tvivl, er det godt, at Jahve selv kan sætte tingene på plads. Det gør han i Salme 50, hvor han overordnet set har et positivt forhold til blodige ofre. Det fremgår eksempelvis af salmens sidste vers: "Den, der bringer takoffer, ærer mig, ham lader jeg se Guds frelse.” Det er bare vigtigt, at man nu også forstår,

40. Eksempelvis i 3 Mos 1,9. DO skriver blot "offer", og derved går læseren glip af emfasen. Se diskussionen i Eberhart (2004) og Eberhart (2002), 40-47 og 318-321. Milgrom oversætter med "food gift" (1991), 161-162. 
hvordan tingene hænger sammen, og det får vi nogle vers længere oppe: "Jeg tager ikke tyre fra dit hus eller bukke fra dine folde, for alt skovens vildt er mit, dyrene på de tusinder af bjerge. Jeg kender alle fuglene i bjergene, markens dyr tilhører mig. Bliver jeg sulten, siger jeg det ikke til dig, for jorden er min, med alt, hvad den rummer. Behøver jeg at spise tyrekød eller drikke bukkeblod?" Jahve sætter pris på ofrene, det kan også godt være at Jahve spiser ofrene på sin egen måde, nemlig med næsen, men han kan sagtens klare sig uden. Jahve er ikke afhængig af mennesker, og de ofre de giver ham. Eller for at udtrykke det på nudansk, for Jahve er ofre "nice-to-have", ikke "need-to have". Men det stopper ikke her, for hver gang man har noget, der minder om en entydig holdning i Det Gamle Testamente, er der altid mindst én tekst, der siger noget andet. I Første Mosebog 18 kan man læse historien om Abraham, der får besøg af tre mænd, der i virkeligheden er Jahve. Historien ender med ødelæggelsen af Sodoma og Gomorra, men inden vi når dertil, udviser Abraham forbilledlig gæstfrihed og byder de tre mænd på frokost. Abraham sætter straks Sara i gang med at bage brød, og så tager han selv tykmælk og mælk og en kalv, som er blevet tilberedt, og han serverer det for dem, og som der står, "Selv stod han hos dem, mens de sad og spiste under træet." Abraham og Jahve spiser altså ikke sammen, for Abraham spiser ikke, men Jahve spiser helt almindeligt, må vi gå ud fra, med munden og ikke med næsen, og han beder ikke om at få måltidet konverteret til et brændoffer.

I denne sammenhæng er det relevant at overveje, om børneofre også er en af de gaver, som Jahve gerne vil have. Jeg kan lige så godt løfte sløret for konklusionen med det samme, for ifølge Det Gamle Testamente, vil Jahve nok egentlig ikke have børneofre, men det er ikke en konklusion, som forfatterne når frem til uden kvaler, for der er noget ved børneofferet, der er så rigtigt i forhold til gavens teologi, at det er svært at komme udenom. Lad os starte med førstefødselsofferet. I Anden Mosebog 13,1-2 står der, "Du skal hellige mig alle førstefødte. Alt det første, der kommer ud af moderlivet hos israelitterne, skal tilhøre mig; det gælder både mennesker og kvæg." ${ }^{41}$ I forhold til gavens logik, så giver det rigtig god mening, at de førstefødte tilhører Jahve, ligesom førstegrøden også gør det, for det kommer nemlig alt sammen fra ham. Som der står i Femte Mosebog 7: "[Jahve] vil elske dig og velsigne dig og gøre dig talrig; han vil velsigne frugten af dine moderliv og frugten af din jord, dit korn, din vin og din olie, dine oksers afkom og dine fårs tillæg på den jord, som han lovede dine fædre at give dig. Du bliver velsignet frem for alle andre folk; der skal ikke fin-

41. Jf. $2 \operatorname{Mos} 22,28-29$. 
des nogen ufrugtbar mand eller kvinde hos dig, og noget ufrugtbart dyr." Gaven er målrettet og personlig og altid tilpasset lejligheden. Gaven afspejler relationen mellem giver og modtager. Derfor, når nu alle børn, både dyrebørn og menneskebørn, kommer fra Jahve, virker det kun rimeligt, at han også får lidt af dem igen, som en form for anerkendelse, en markering af at Jahves gaver er værdsatte (jf. Lundager Jensen 2011, 6-7; Gudme 2013, 30-31).

Men nu er det jo Det Gamle Testamente vi har med at gøre, så aldrig så snart har vi fået en tilsyneladende utvetydig befaling om at ofre alle førstefødte til Jahve, førend vi får en anden lov, der modererer udsagnet: "Alt det første, der kommer ud af moderlivet, skal tilhøre mig, det gælder alle handyr af dit kvæg, det førstefødte af okser og får. Det førstefødte æsel kan du frikøbe med et stykke småkvæg. Vil du ikke frikøbe det, skal du brække halsen på det. Enhver førstefødt blandt dine sønner skal du frikøbe. Tomhændet må ingen se mit ansigt" (2 Mos 34). ${ }^{42}$ I princippet burde man altså ofre sine førstefødte børn til Jahve, men Jahve har sørget for, at det alligevel ikke er nødvendigt ved at introducere en frikøbsordning.

I det hele taget gør Det Gamle Testamente sig stor umage for at fremstille børneofre som en fremmed og vederstyggelig skik, der på ingen måde har noget med Jahvereligionen at gøre. ${ }^{43}$ Skulle man alligevel være i tvivl, sætter Jahve selv tingene på plads, eksempelvis i Jeremias' Bog 7, hvor Jahve anklager Jerusalems indbyggere: “De har bygget Tofets offerhøje i Hinnoms søns dal for at brænde deres sønner og døtre. Det har jeg aldrig befalet eller haft i tankerne.”44

På trods af, at de fleste tekster i Det Gamle Testamente tager afstand fra børneofre, bliver der ofret to børn i Det Gamle Testamente. Den første er Jeftas datter i Dommerbogen 11, og hun tæller næsten ikke, for den historie handler mest af alt om, at man skal holde, hvad man lover. ${ }^{45}$ Jefta afgiver et sjusket formuleret løfte til Jahve, hvor han

42. Jf. 2 Mos 13,14-16, hvor frikøbet kædes sammen med drabet på Egyptens førstefødte, og 4 Mos 3, 12-13, hvor levitterne udpeges som erstatning for Israels førstefødte.

43. Jf. 3 Mos 18,21 og 20,2-5; 5 Mos 12,31; 2 Kong 16,3 og 21,6. Se også Francesca Stavrakopoulou, King Manasseh and Child Sacrifice: Biblical Distortions of Historical Realities (Berlin: De Gruyter 2004), 141-316.

44. Jf. Jer 19,5-7; 32,35. Se også det foruroligende udsagn i Ez 20:25-26, hvor Jahve fremstiller børneofre som en lidt aparte form for prøve eller straf:” Så gav jeg dem love, som ikke var gode, og bud, som de ikke kunne bevare livet ved; jeg gjorde dem urene ved deres gaver, når de ofrede alt det, der kom først ud af moderlivet. Så kunne jeg slå dem med rædsel, for at de skulle forstå, at jeg er Herren.”

45. Jf. Anne Katrine de Hemmer Gudme, "Practice behind the Text? The Conditional Vow in the Hebrew Bible Narrative Texts", Text and Ritual, red. Anne Katrine de Hemmer Gudme (København: Københavns Universitet 2009), 69-79. 
lover at ofre det første, der kommer ud af døren til hans hus, når han vender sejrrig hjem fra krigen. Det er Jeftas elskede datter og eneste barn, der kommer stormende ud af døren, for at byde ham velkommen hjem, og så fanger bordet, og pigen må ofres som et brændoffer til Jahve. I modsætning til historien om nær-ofringen af Isak i Første Mosebog 22, så sker der intet mirakel i sidste øjeblik. Abrahams hånd med kniven bliver standset af et råb fra Jahves engel, og Isak overlever. Sådan går det ikke med Jeftas datter, som dør på alteret.

Det andet barn er kongen af Moabs førstefødte søn i Anden Kongebog 3. Moab er i krig med Israel, og israelitterne har krigslykken med sig. Til sidst er moabitterne næsten slået, og de er belejrede i byen Kir-Hareset. Men så sker der noget: "Da tog [kongen] sin førstefødte søn, der skulle være konge efter ham, og bragte ham som brændoffer på muren. Der kom stor vrede over Israel, og de brød op og vendte tilbage til deres land." 46

Jahve vil ikke have børneofre, men de virker. Det er historien om kronprinsen af Moab et rigtig godt eksempel på. Der er noget så overvældende rigtigt over princippet med børneofre i forhold til gavens teologi, for det er Jahve, der giver afkom, og derfor har han også krav på at få afkom igen. ${ }^{47}$ Samtidig er det også sådan, at enhver giver i overensstemmelse med sin formån. Der er ikke i sig selv noget mærkeligt $\mathrm{i}$, at mennesker giver mindre gaver end Jahve - det er ligesom eksemplet med Lego-borgen og det hjemmelavede askebæger - mennesker giver mindre gaver end Jahve, fordi mennesker kun er ganske små i forhold til Jahve. På den anden side, hvis man virkelig ønsker relationen og den anden parts velvilje, så må man også give noget, der betyder noget for en. Vi kender godt udtrykket, at man kun skal give gaver, som man selv kunne tænke sig, og hvad er mere dyrebart end ens eget barn?

46. Jeg skylder Søren Holst og Niels Peter Lemche tak for deres kommentarer angående 2 Kong 3. I min forelæsning sagde jeg ganske uden at rødme, at Mesha af Moab ofrer til Jahve, hvorefter både Søren og Niels Peter påpegede, at det også er en mulighed, at Mesha ofrer til sin egen gud, Kemosh. Teksten siger hverken det ene eller det andet, og det er i sig selv besynderligt, men imod en identifikation af modtageren af børneofferet med Kemosh taler, at resultatet er en stor vrede, der kommer over Israel. Det er usædvanligt i GT, at fremmede guder har lov til, endsige magt til, at knægte Israel (jf. Reinhard G. Kratz, "Chemosh's Wrath and Yahweh's No: Ideas of Divine Wrath in Moab and Israel", Divine Wrath and Divine Mercy in the World of Antiquity, red. Reinhard G. Kratz \& Hermann Spieckermann (Göttingen: Mohr Siebeck 2008), 92-121 (106-109). Se også diskussionen i Stavrakopoulou (2004), 176-178.

47. Se Ole Davidsen, "Og Gud sagde til Abraham: Om pagt, omskærelse og offer i Abrahamshistorien”, RvT 27 (1995), 79-118. 
Det er denne usvigelige logik i gavens teologi, som Det Gamle Testamente kæmper med, når det diskuterer børneofre, for når nu det er så indlysende rigtigt, at Jahve har både krav på og vil synes om, at vi ofrer de førstefødte, hvordan kan det så være, at han alligevel ikke vil have dem? Svaret giver teksten med historien om Abraham; i princippet vil Jahve gerne have dem, men han er villig til at stille sig tilfreds med, at vi $i$ princippet er parat til at give dem fra os.

\section{Kultkritik}

Når man læser Det Gamle Testamente, kan der ikke være nogen tvivl $\mathrm{om}$, at Jahve vil have ofre. En stor del af åbenbaringen på Sinajbjerget i Anden Mosebog går med at ordne rammerne for, hvordan folket kan give Jahve gaver i form af ofre, når de besøger ham i templet. Derfor virker det også lidt overraskende, når Jahve i nogle tekster pludselig vender sig imod ofrene. Det er de såkaldt kultkritiske passager, illustreret med et klassisk eksempel her i form af Amos' Bog 5,21$22: 48$ "Jeg hader og forkaster jeres fester, jeg bryder mig ikke om jeres festdage. Når I bringer mig jeres brændofre og afgrødeofre, tager jeg ikke imod dem, og måltidsofre af jeres fedekvæg vil jeg ikke se." Det fremgår klart, at Jahve ikke vil vide af Israels ofre, og passager som denne er da også traditionelt blevet tolket som et udtryk for, at man især i profetlitteraturen finder en gren af Jahvereligionen, der er kritisk eller ligefrem fordømmende over for offerkulten og præsteskabet. Når Jahve fortsætter i Amos' Bog og siger, "Fri mig for lyden af dine sange, dine harpers klang vil jeg ikke høre! Men ret skal strømme som vand, retfærdighed som en stadig rindende bæk.", så er det ofte blevet udlagt som profeternes særlige etiske udgave af Jahvereligionen, hvor man prioriterer moralsk adfærd og lydighed overfor Jahve frem for offerkultens mere eller mindre primitive forsøg på at bestikke guden med afbrændte dyr.

Der er adskillige problemer med den tolkning af de kultkritiske passager i Det Gamle Testamente. For det første er der intet der tyder

48. Kultkritikken i Det Gamle Testamente forbindes først og fremmest med profetlitteraturen og særligt med passager som Hos 6,6; Mika 6,6-8; Es 1,10-17; Jer 6,20 og 7,21-26. Der er dog også eksempler på kultkritik i visdomslitteraturen og i salmerne, se Leo G. Perdue, Wisdom and Cult: A Critical Analysis of the Views of Cult in the Wisdom Literatures of Israel and the Ancient Near East (SBL Dissertation Series 30) (Atlanta: Scholars Press 1976) og Alexander B. Ernst, Weisheitliche Kultkritik: Zu Theologie und Ethik des Sprüchebuchs und der Prophetie des 8. Jahrhunderts (Neukirchen-Vluyn: Neukirchener 1994). 
på, at offerkulten skulle være særlig uetisk eller uinteresseret i moralske spørgsmål, eller at profetlitteraturen for den sags skyld skulle se sig selv som løsrevet fra kulten. ${ }^{49}$ For det andet er det ofte en fejlagtig forstålse af gaven, der får folk til at gå ud fra, at offerkulten skulle være mindre etisk, end et religiøst system uden ofre. Hvis man forstår gaver til Gud som bestikkelse, forsøg på at købe sig til guds velvilje eller opmærksomhed, er det klart, at offerkulten kommer til at se noget anløben ud. Hvis man samtidig forestiller sig, at bytteforholdet i forbindelse med offeret er automatisk eller mekanisk, således at man er fri til at gå ud og undertrykke de svage og stjæle fra de fattige, når bare man har bragt sine ofre i templet, ser det naturligvis heller ikke så godt ud. Men hvis vi holder fast i gavegivning som en relationsskabende udveksling, der handler om de involverede parter og ikke om de udvekslede genstande, får vi mulighed for både at afvise kritikken om, at offerkulten i sig selv skulle være uetisk, og vi får en nøgle til at forstå de såkaldt kultkritiske tekster i Det Gamle Testamente. ${ }^{50}$ Det vil jeg illustrere med endnu et eksempel, denne gang fra Esajas' Bog 1,11-17: "Hvad skal jeg med jeres mange slagtofre? siger Jahve. Jeg er mæt af brændofre af væddere og fedtet af fedekvæg; blod af tyre, lam og bukke vil jeg ikke have. Når I kommer for at se mit ansigt, hvem kræver så af jer, at mine forgårde bliver trampet ned? Bring ikke flere tomme afgrødeofre, røgelsesoffer væmmes jeg ved. Nymånedag og sabbat, festforsamling - jeg kan ikke udholde festdag og ondskab; jeg hader jeres nymånedage og fester, de er blevet en byrde, jeg ikke kan bære. Når I rækker hænderne frem imod mig, lukker jeg øjnene; hvor meget I end beder, hører jeg det ikke. Jeres hænder er fulde af blod, vask jer, rens jer! Fjern jeres onde gerninger fra mine øjne, hold op med at handle ondt, lær at handle godt! Stræb efter ret, hjælp den undertrykte, skaf den faderløse ret, før enkens sag!"

Men hvad er det egentlig Jahve siger her? Er det ofre i det hele taget han siger nej til? Nej, det er specifikt "jeres brændofre". Det er Juda og Jerusalems brændofre, som Jahve ikke vil have, fordi folket har blod på hænderne, og udfører onde gerninger. Jahve vil altså ikke modtage folkets offergaver, fordi han ikke vil have noget med folket at gøre. Han er vred på dem, fordi de har opført sig forkert, og derfor lukker han øjnene, når de tropper op i templet belæsset med gaver. Jahve afviser relationen til sine tilbedere, fordi han er utilfreds med deres opførsel, og derfor nægter han også at modtage deres gaver. Der

49. Jf. Perdue (1976); Ullucci (2011), 31-63.

50. Jf. Ullucci (2011) og Göran Eidevall, Sacrificial Rhetoric in the Prophetic Literature of the Hebrew Bible (Lampeter: The Edwin Mellen Press 2012), som begge bruger en nuanceret forståelse af offeret som gave til at danne grundlag for en diskussion af de såkaldt kultkritiske tekster. 
er ikke nogen automatik på færde her. Gaven er altid til forhandling. Når først en gave er givet som en invitation eller udfordring, så har modtageren krammet på en, og lige nu har Jahve krammet på folket, og Jahve siger nej!

Men betyder det, at Jahve har sagt nej til offergaver i al evighed? Det gør det naturligvis ikke. Jahve giver selv opskriften på, hvordan relationen kan repareres: "lær at handle godt!" Hvis bare folket begynder at opføre sig ordentligt, vil Jahve igen sige ja tak, når de bringer ham gaver. De kultkritiske tekster i Det Gamle Testamente er altså ikke udtryk for, at Jahve for tid og evighed har forkastet offeret som en acceptabel gave. De er udtryk for, at Jahve har set sig gal på sine tilbedere, og derfor forkaster han dem og således også de gaver, de ønsker at give ham, indtil videre.

\section{Begyndelsen til enden på det blodige offer}

I det foregående har jeg beskrevet ofrene i Det Gamle Testamente, som om de var virkelige ofre, og ikke bare tekst. Og det kan man også godt. Det er ualmindelig vigtigt for at kunne forstå et fænomen som offeret i en gammeltestamentlig kontekst, at man har et kendskab til ritualteori og til sociale fænomener og praksisser, såsom gavegivning. Det hjælper en til at forstå, hvordan det blodige offer fungerer i teksten, og hvilken relativ værdi det har i teksten. Men man må aldrig glemme, at det man har foran sig er en tekst, det er ikke et ritual. Et rigtigt ritual ser helt anderledes ud, og i det blodige offers tilfælde involverer det en hel del mere brægen og bløden end Tredje Mosebog nogensinde har gjort.

Jeg tilhører stadig et mindretal på dette punkt, men jeg mener ikke, at man kan slutte fra tekst til virkelighed, og jeg tror ikke, at eksempelvis Tredje Mosebog er blevet skrevet som en form for håndbog for præster. ${ }^{51}$ Der kan sagtens være en lang række lighedspunkter mellem det blodige offer som det engang blev praktiseret i jernalderens $\mathrm{Pa}$ læstina, og det ritual vi får beskrevet i Det Gamle Testamente, men arkæologien har vist os, at der bestemt også er forskelle. ${ }^{52}$ Min pointe er, at vi ikke bare kan gå ud fra, at teksten svarer til ritualet, og det er ualmindelig vigtigt, for et ritual er adfærd, handlinger, hvorimod en

51. Jeg har været inde på denne diskussion før, se Gudme (2009).

52. Et rigtig godt eksempel på en uoverensstemmelse mellem ritualtekster i Det Gamle Testamente og arkæologiske lev er udvalget af offerdyr. Se Oded Borowski, "Animals in the Religion of Syria-Palestine," A History of the Animal World in the Ancient Near East, red. Billie Jean Collins (Leiden: Brill 2002), 405-424. 
tekst er en tekst, og det er et metodisk fejltrin ikke at tage den forskel alvorligt.

I bund og grund hælder jeg til den opfattelse, at produktionen af litteratur om det blodige offer, markerer begyndelsen til enden på det blodige offer. For så længe ritualet er tilgængeligt, så er der ikke noget behov for teksten om ritualet. Teksten bliver først for alvor vigtig og dyrebar, når templet og ritualerne er uden for rækkevidde. ${ }^{53}$ Det Gamle Testamente er i sig selv et eksempel på den udvikling Jahvereligionen undergik i slutningen af det 1 . årtusinde $\mathrm{f}$. Kr., nemlig fra kult- eller tempel-religion til "bog-religion". Der er ingen tvivl om, at det var en meget kompleks udvikling, hvor flere forskellige faktorer, idehistoriske såvel som politiske, har været afgørende, men en del af den udvikling er, at det blodige offer gik fra at være et centralt ritual i tempelkulten til at være et gradvist mere og mere abstrakt symbol, der primært optrådte i tekster. Denne udvikling vil jeg give et enkelt eksempel på, nemlig hvordan det blodige offer ændrer karakter i den såkaldt "intertestamentariske" periode, dvs. fra ca. 200 f. Kr. og frem til midten af det 1 . århundrede e. Kr.. ${ }^{54}$ I en mesopotamisk visdomstekst, der hedder Visdommens råd, kan man læse følgende opfordring til, hvordan man skal omgås de fattige: "Giv mad at spise og øl at drikke. Giv, hvad der bliver bedt om, sørg for [dem] og ær [dem]. Ved dette finder en mands gud behag. Det behager Šamaš, som vil gengælde hans tjeneste. ${ }^{55}$ Gør gode gerninger, gør tjenester alle dine dage." ${ }^{56}$ Denne tekst giver udtryk for, at man kan komme til at stå i en positiv relation til solguden Samaš ved at være god ved de fattige. Hvis man er det, vil Šamaš til gengæld vil gøre en en tjeneste. Denne passage fra Visdommens råd minder i påfaldende grad om Ordspro-

53. Jeg fremfører et lignende argument om tempelteksterne i 2 Mos 25-40 i artiklen, "Dyed Yarns and Dolphin Skins: Temple Texts as Cultural Memory in the Hebrew Bible", Jewish Studies 50, (2014), 1-14.

54. Diskussionen i det følgende er delvist baseret på mit paper, "Whoever is kind to the poor lends to the Lord, and will be repaid in full" (Prov 19:17): Patterns of Indirect Reciprocity in the Book of Proverbs and in the Sermon on the Mount," som blev præsenteret i Helsinki i januar 2014, og som nu er under udgivelse i et konferencebind, redigeret af Rikard Roitto og Petri Luomanen.

55. Jeg har valgt at oversætte dumqu i linje 64 med "tjeneste". Lambert skriver "favour". dumqu kan betyde noget godt eller velfærd, men det kan også betyde belønning eller modtjeneste. Læg mærke til sammenfaldene mellem betydningen a dumqu og det græske kharis, se Gudme 2013, 141-142 og Robert Parker, "Pleasing Thighs: Reciprocity in Greek Religion," Reciprocity in Ancient Greece, red. Christopher Gill, Norman Postlethwaite \& Richard Seaford (Oxford: Oxford University Press 1998), 105-126.

56. Counsels of Wisdom, linje 61-65, W.G. Lambert, Babylonian Wisdom Literature (Oxford: At The Clarendon Press 1960), 102-103. 
genes Bog 19,17:57 "Den, der forbarmer sig over den svage, giver et lån til Jahve, og Jahve gengælder ham hans gerning." Her ser vi et eksempel på en alternativ vej til at få en positiv relation til guden, det være sig Jahve eller Šamaš. I forbindelse med almindelig gavegivning er der tale om direkte reciprocitet eller udveksling: Jeg giver til Jahve, og Jahve giver til mig. Eksemplet her fra Visdommens råd og fra Ordsprogenes Bog er til gengæld et eksempel på indirekte reciprocitet: Jeg giver til den fattige, og Jahve giver til mig. Vi har to former for reciprocitet repræsenteret i teksten, direkte og indirekte, og de udelukker for så vidt ikke hinanden. Begge former for reciprocitet er en legitim vej til at etablere en positiv relation til guddommen.

Hvis vi hopper nogle hundrede år frem i tiden, sker der noget. I Tobits Bog, som formodentlig stammer fra det 2. århundrede f.Kr., formaner Tobit sin søn, Tobias, og siger: "Alle, der handler retfærdigt, skal du give almisse af det, du ejer, og du må aldrig vende dit ansigt bort fra den fattige. Så vil Gud heller ikke vende sit ansigt bort fra dig. Du skal give, alt efter hvad du ejer, min dreng: Har du meget, så giv almisse af det; har du kun lidt, så giv svarende til det, du har. Du må altså ikke være bekymret, min dreng, når du giver almisse; du samler en god skat til dig selv på nødens dag! For almisse redder fra døden og hindrer, at man går ind i mørket. Almisse er for alle, der giver den, en god offergave bragt frem for den Højeste!"

I Tobits Bog bliver det at give almisse til de værdigt trængende fremhævet som noget, der er lige så godt eller svarer til det blodige offer. ${ }^{58}$ Hvor parallellen til offeret i Visdommens råd og i Ordsprogenes Bog var implicit, fordi både offer og almisse er en vej til den gode relation til gud, så har vi her en eksplicit sammenligning, hvor konklusionen er, at almisse er det samme som, og lige så gavnligt som, "en god offergave bragt frem for den Højeste". 59 Her ser vi et konkret eksempel på begyndelsen til enden på det blodige offer i Det

57. Jeg blev opmærksom på denne passage i Visdommens råd og på lighederne med Ordsp 19,17, da jeg læste Perdue (1976), 100-101. Perdue nævner ikke selv lighederne mellem de to tekster mht. de fattige, og jeg er heller ikke umiddelbart faldet over andre, der forbinder de to. Jeg kan dog ikke forestille mig, at det ikke skulle være tilfældet, at andre har opdaget lighederne.

58. Gary A. Anderson, "Redeem Your Sins by the Giving of Alms: Sin, Debt, and the 'Treasury of Merit' in Early Jewish and Christian Tradition", Letter \& Spirit 3 (2007), 39-69; Gary A. Anderson, "A Treasure in Heaven: The Exegesis of Proverbs 10:2 in the Second Temple Period", Hebrew Bible and Ancient Israel 1 (2012), 351367.

59. Gary A. Anderson har formodentlig ret i, at Tobits bog til dels promoverer almisse som et alternativt offer i en diaspora-kontekst, se "You will have a Treasure in Heaven", New Approaches to the Study of Biblical Interpretation in Judaism of the Second Temple Period and in Early Christianity, (red.) Gary A. Anderson, Ruth A. Clements \& David Satran (Leiden: Brill 2013), 107-132 (117). 
Gamle Testamente. Det blodige offer som gave bliver et ideal, et sammenligningspunkt, en abstraktion, der indeholder et enormt fortolkningsmæssigt potentiale, men det blodige offer i sig selv, selve ritualet, mister gradvist sin betydning. I år 70 e.Kr. bliver templet i Jerusalem $ø$ delagt, og denne begivenhed har naturligvis været en vigtig del af forklaringen på offerkultens ophør, men det er værd at notere sig, at det blodige offers endeligt allerede var i gang. Man var allerede i gang med at tænke i nye baner og fremhæve nye praksisser, der erstattede det blodige offer som det mest centrale ritual i forholdet til Jahve. Det blodige offer forsvandt fra den religiøse praksis, ligesom tempelkulten forsvandt, og i deres sted kom teksten endegyldigt i centrum, og det er i den form, det blodige offer i Jahve-religionen er bevaret for os i dag. Det er derfor, det blodige offer er blevet eksotisk og fremmed, og at vi forsøger at sætte det på formler, der giver mening for os såsom gavens teologi. 